\title{
Australian Journal of

\section{Seed desiccation and salinity tolerance of palm species Carpentaria acuminata, Dypsis decaryi, Phoenix canariensis, and Ptychosperma elegans}

\author{
Gisele Sales Batista ${ }^{1}$, Renata Bachin Mazzini-Guedes ${ }^{2 *}$, Kathia Fernandes Lopes Pivetta ${ }^{1}$, Hugh W. \\ Pritchard $^{3}$, and Tim Marks ${ }^{3}$
}

${ }^{1}$ Department of Crop Production, College of Agricultural and Veterinary Sciences, State University of São Paulo (FCAV/UNESP), Via de Acesso Professor Paulo Donato Castellane, s/n, CEP 14884-900, Jaboticabal/SP, Brazil

${ }^{2}$ Federal University of Paraná (UFPR), Rua Doutor João Maximiano, 426, Vila Operária, CEP 86900-000, Jandaia do Sul/PR, Brazil

${ }^{3}$ Royal Botanic Gardens, Kew, Wakehurst Place, Ardingly, West Sussex RH17 6TN, United Kingdom

*Corresponding author: remazzini@ yahoo.com.br

\begin{abstract}
Desiccation-sensitive seeds lose water quickly, what is an important feature to determine their ability to tolerate periods of seasonal drought. Furthermore, excess of soluble salts on seed germination causes a reduction in the substrate water potential. The objective of this study was to assess the desiccation and salinity tolerance of seeds of four ornamental palm species. Different moisture contents were studied for seeds of Carpentaria acuminata, Dypsis decaryi, Phoenix canariensis, and Ptychosperma elegans, while five concentrations of $\mathrm{NaCl}$ were tested separately for $C$. acuminata and $P$. elegans. Seeds of $C$. acuminata and $P$. canariensis tolerated drying at 5\% and $8 \%$ seed moisture, respectively. On the other hand, seeds of $D$. decaryi and P. elegans were sensitive to dehydration even at high moisture contents, $20 \%$ and $27 \%$ of seed moisture, respectively. Increase on salt concentration did not affect germination or germination rate of $C$. acuminata and P. elegans seeds.
\end{abstract}

Keywords: Arecaceae; electrical conductivity; moisture content; ornamental palms; recalcitrant seed; salt stress.

Introduction

Carpentaria acuminata (H. Wendl. \& Drude) Becc., Dypsis decaryi (Jum.) Beentje \& J. Dransf., Phoenix canariensis Hort. ex Chabaud, and Ptychosperma elegans (R. Br.) Blume, in the family Arecaceae, are exotic ornamental palms widely used both in the Brazilian landscape and worldwide.

Many plant species produce 'desiccation-sensitive' seeds, i.e., seeds that lose viability according to dehydration (Tweddle et al., 2003). Desiccation tolerance varies among species (Berjak and Pammenter, 2008) and is determined by the seed critical moisture content that, in turn, is related to the amount of water loss that leads to viability decrease. Equally important, is the period that a seed can withstand desiccation before death (Hill et al., 2010). It is well-known that the drying rate may influence the behavior of desiccationsensitive seeds (Maluf et al., 2003), but very little is known about their most basic properties. That is, how whole seeds lose water and whether patterns of water loss are consistent in all species (Hill et al., 2010).

Seeds may be classified as orthodox, recalcitrant, and intermediate according to their degree of desiccation tolerance (Roberts, 1973). Most palm seeds are treated as recalcitrant, in which viability is reduced when their moisture content reaches values lower than those considered critical. Therefore, when it is equal or lower than those considered lethal, there is total loss of viability (Martins et al., 1999a).

Plant germination becomes also critical under saline environments, which conditions are one of the main factors that reduce plant establishment and crop yield. At such stage, plants are more sensitive to environmental stresses that may lead to injuries and, under extreme conditions, plant death (Ditommaso, 2004; Jaleel et al., 2007). Furthermore, according to El Rabey et al. (2015), a high salinity affects the whole plant and may lead to water deficit stress, metabolic toxicity, nutritional deficiencies and, finally, a drastic yield reduction.

On the other hand, several species may be favored when exposed to sodium chloride $(\mathrm{NaCl})$ (Tester and Davenport, 2003). Certain plants even benefit from salinity during germination, what provides them greater adaptability to such condition during the remainder of their cycle (Viana et al., 2004). However, success of seed germination also depends on the water movement through the tissues surrounding the seed. Therefore, salt presence affects the soil water potential, reducing such potential gradient between soil and seed surface and restricting water uptake by the seed (Lopes and Macedo, 2008).

As there are contradictory results in the literature related to palm species, our objective was to determine the behavior of Carpentaria acuminata, Dypsis decaryi, Phoenix canariensis, and Ptychosperma elegans seeds to desiccation, as well as of C. acuminata and P. elegans seeds to salinity. 


\section{Results and Discussion}

Seeds of Carpentaria acuminata, Dypsis decaryi, Phoenix canariensis, and Phoenix elegans show different responses to desiccation

High moisture contents, which were observed soon after harvest in seeds of all species, affected both germination and germination rate (Fig 1, Fig 2, Fig 3), with the exception of C. acuminata seeds. This species was the only one that did not present a significant adjustment probably because the fruits were not completely physiologically mature at harvest. Therefore, germination percentage and germination rate for C. acuminata seeds were not significantly influenced by their moisture contents. They kept their germination rate as high as, greater than $70 \%$, regardless of drying. Thus, both critical and lethal moisture contents for seeds of this species were not observed. However, C. acuminata seeds germinated slower than the other species. Regarding $D$. decaryi, germination percentage and germination rate increased as seed moisture content decreased from 56.3 to $25 \%$. Highest percentage and fastest germination were observed at $25 \%$ seed moisture content, whereas at lower percentages the variables gradually decreased. The critical seed moisture content for this species ranged from 10 to $15 \%$, while the lethal one was not observed (Fig 1).

Germination percentage of $P$. canariensis seeds increased as their moisture content decreased from 45 to $35.2 \%$, whereas at lower rates germination gradually decreased. Neither critical nor lethal seed moisture contents were observed for this species, as germination percentage remained higher than $76 \%$. However, as it decreased, seeds germinated more slowly (Fig 2).

For $P$. elegans seeds, germination percentage and germination rate increased as seed moisture content decreased from 42.9 to $32 \%$. Highest percentage and fastest germination were observed at $32 \%$ seed moisture content, while in lower rates the variables gradually decreased. Critical and lethal seed moisture contents for this species were $17-22 \%$ and $7-12 \%$, respectively (Fig 3). Seeds of $C$. acuminata and $P$. canariensis maintained high germination percentage even at low seed moisture contents ( 8 and $5 \%$, respectively), evidencing that these species are tolerant to desiccation. On the other hand, $D$. decaryi and $P$. elegans seeds demonstrated to be sensitive to desiccation, as germination percentage gradually decreased even at high seed moisture levels (20 and 27\%, respectively).

The sensitivity of recalcitrant seeds to desiccation, as well as the critical and lethal levels of seed moisture content, influence germination responses and is species-dependent, as these levels were not observed for all studied species. However, several authors have already described them for some palms, such as Euterpe espiritosantensis Fernandes (40.7-51.4\% and 13.4-15.8\%, respectively) (Martins et al., 1999a), Euterpe oleracea Mart. (34.2-36.4\% and 17.4-18.9\%, respectively) (Martins et al., 1999b), and Bactris gasipaes Kunth (23-28\% and 13.9-15\%, respectively) (Bovi et al., 2004). However, authors may usually differ to what concerns those levels. Carvalho and Müller (1998), found that seed moisture content levels of tolerance and lethality for $B$. gasipaes were 30 and $12 \%$, respectively. Moreover, according to Ferreira and Santos (1992), seed viability of same species is affected by low seed moisture contents, in which under $38 \%$, germination and vigor are rapidly decreased. Also, at or lower than $17 \%$ moisture contents the germination was very low. Also, as described by Martins et al. (2003), seeds of Archontophoenix alexandrae (F. Muell.)
H. Wendl. \& Drude kept under 31.5\% seed moisture content or lower, significant reduction is germination was observed, while total loss occurred when it reached $15.1 \%$. Furthermore, Dias et al. (2015) found that seed moisture content as low as $5 \%$ did not affect viability and vigor of Butia capitata (Mart.) Becc. seeds, species that is considered intermediate/orthodox.

Some studies also show positive correlations between moisture content and germination of palm seeds. For Oenocarpus mapora H. Karst. seeds, Carvalho et al. (1998) obtained $86 \%$ germination at $31.8 \%$ seed moisture content, which was measured immediately after harvest. Nascimento et al. (2002), for that same species, also obtained 92\% germination at $41.3 \%$ seed moisture content.

Additionally, there seems to be a relationship between seed size and desiccation tolerance. Desiccation-sensitive seeds have been reported to be, on average, larger than desiccationtolerant seeds, so seed size would influence the rate of seed drying (Daws et al., 2005). In our study, D. decaryi seeds were larger than the others and were also susceptible to desiccation. However, P. elegans seeds, which were the smallest among the studied species, were also sensitive to dehydration (Table 1). Therefore, only such characteristic is not sufficient to evaluate seed behavior regarding sensitivity to desiccation.

C. acuminata and $P$. canariensis seeds proved to be tolerant to desiccation. Dickie and Pritchard (2002) suggested that desiccation tolerance was part of the seed ancestral state and has subsequently been lost in species that produce desiccation-sensitive seeds. The ability to tolerate desiccation is clearly advantageous and enables seed persistence both through time and in relatively arid environments (Pammenter and Berjak, 2000). Nevertheless, according to Pritchard et al. (2004) and Daws et al. (2005), the sensitivity to desiccation, showed by seeds of $D$. decaryi and $P$. elegans, may also be advantageous because rapid seed germination may reduce the time that seed is exposed to predators. However, $P$. canariensis seeds, which is considered desiccation-tolerant, germinated after an average of 13 days, while seeds of $P$. elegans, D. decaryi, and C. acuminata germinated after 17 , 40, and 92 days, respectively (Table 1).

\section{Seeds of Carpentaria acuminata and Phoenix elegans are} salt tolerant

The increase of salt concentrations did not significantly affect germination percentage and germination rate of $C$. acuminata and $P$. elegans seeds, which were, respectively, $80 \%$ and 0.180 , and $71 \%$ and 0.804 , showing that both species are salt tolerant. High salt contents in the soil, especially $\mathrm{NaCl}$, may inhibit germination mainly due to the osmotic effects. In addition, the increment on salt concentrations may produce an increase in the percentage of abnormal seedlings due to the salt toxic action on seeds (Lima et al., 2005). Some species; however, may be favored when exposed to $\mathrm{NaCl}$ concentrations (Tester and Davenport, 2003) at germination time, achieving greater adaptability to salinity along their life cycle (Viana et al., 2004).

In fact, Fernandes et al. (2003) report that species belonging to the family Arecaceae have their growth and production stimulated by the presence of $\mathrm{Na}$. Also, these species require high $\mathrm{Cl}$ contents to express their productive potential completely. Similarly, for Cocos nucifera L. seeds, Marinho et al. (2005) observed that the increment on electrical conductivity did not significantly influence seed germination, which ranged from 80 to $97.5 \%$. On the other hand, it influenced the species germination rate and seedling 
Table 1. Palm species and characteristics of seed batches.

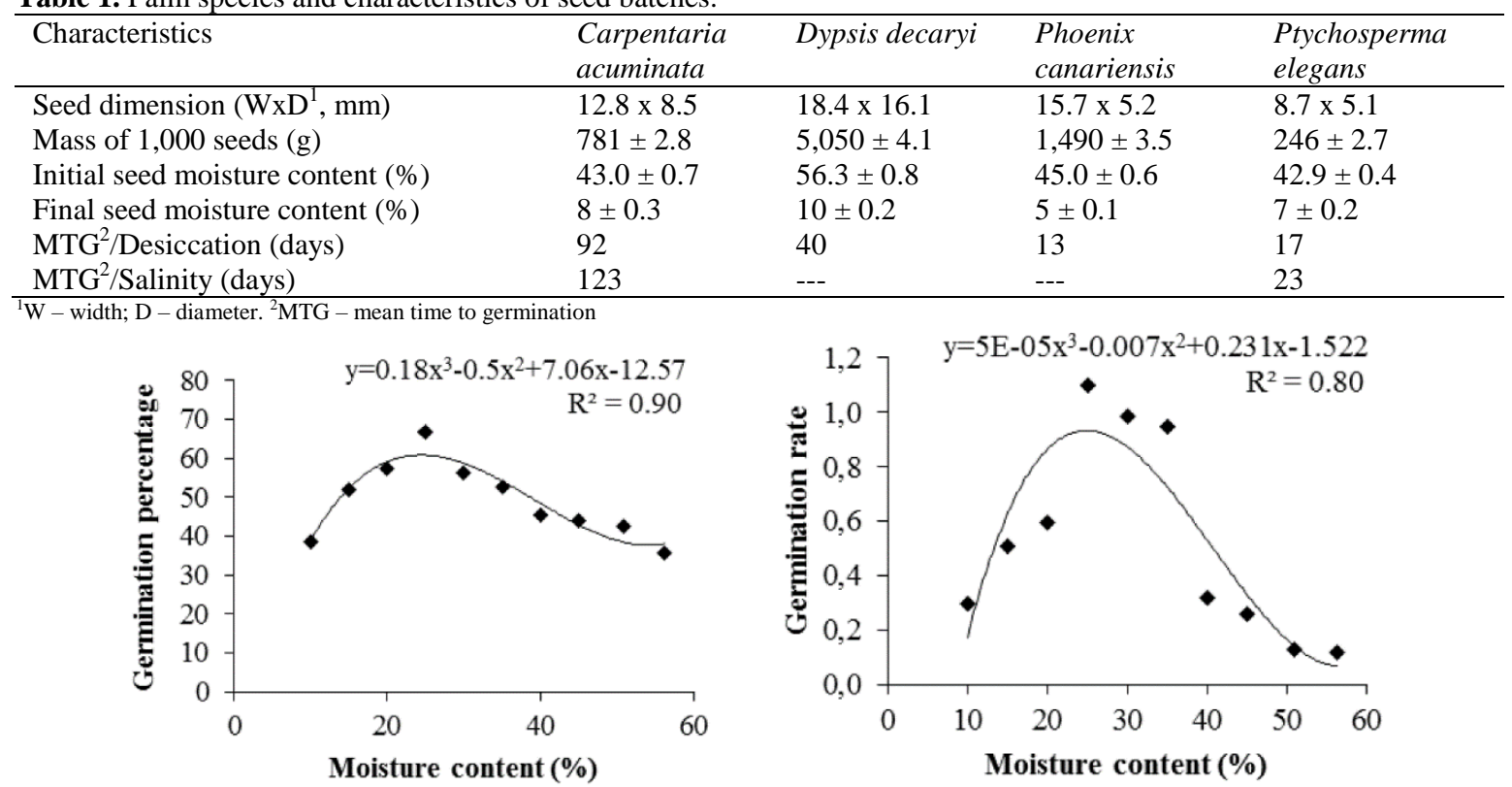

Fig 1. Variations of germination percentage and germination rate of Dypsis decaryi according to different seed moisture contents, Significant at $5 \%$.
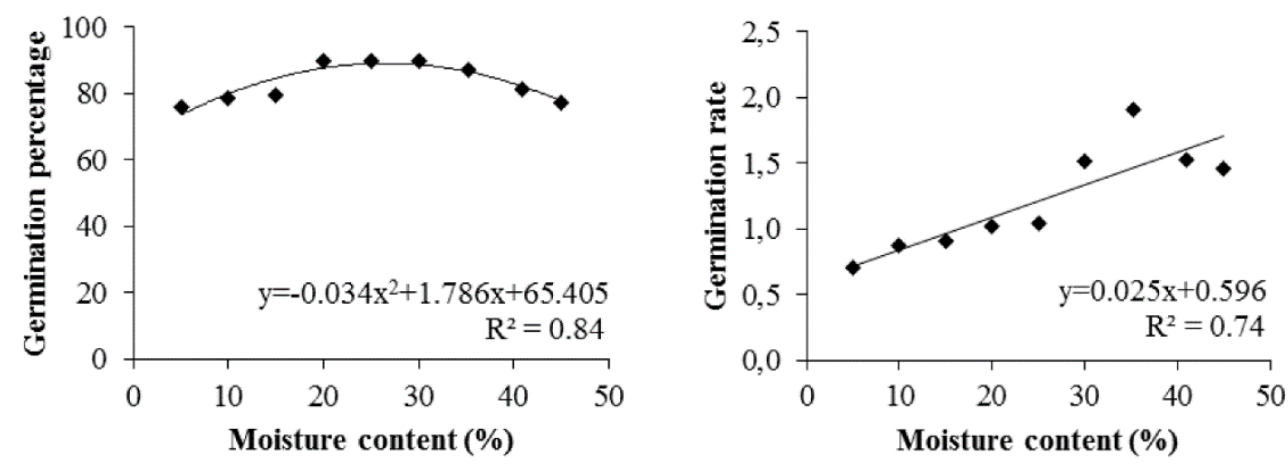

Fig 2. Variations of germination percentage and germination rate of Phoenix canariensis according to different seed moisture contents, Significant at $5 \%$.
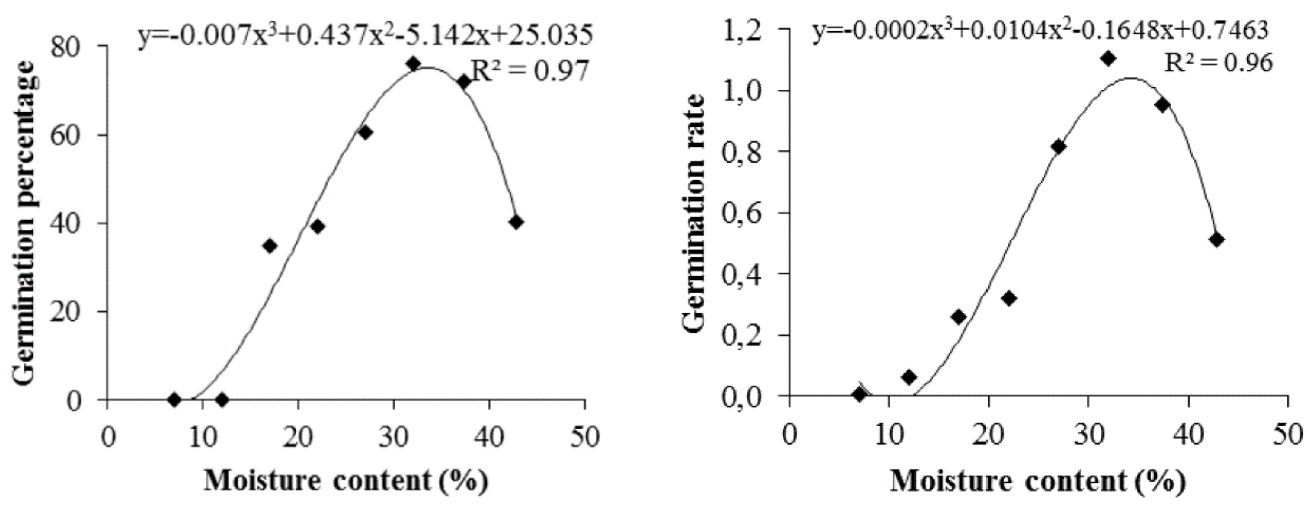

Fig 3. Variations of germination percentage and germination rate of Ptychosperma elegans according to different seed moisture contents, Significant at $5 \%$. 
growth as salinity, from $5.4 \mathrm{dS} \mathrm{m} \mathrm{m}^{-1}$, affected the seed total biomass. In our study; however, salinity did not affect the germination rate, but $P$. elegans seeds did germinate faster (23 days), when compared with $C$. acuminata (123 days) (Table 1).

Martín Alemán et al. (1999) studied the effect of different salt concentrations on germination of $P$. canariensis $(0$ to $27.5 \mathrm{dS} \mathrm{m}^{-1}$ ) and Sabal palmetto (Walter) Lodd. ex Schult. \& Schult. f. (0 to $19.9 \mathrm{dS} \mathrm{m}^{-1}$ ) seeds and observed that 4.9 and $1.6 \mathrm{dS} \mathrm{m}{ }^{-1}$ electrical conductivity, respectively, reduced germination. S. palmetto seeds were then considered more sensitive to salinity than $P$. canariensis.

In general, when considering species behavior regarding salinity and desiccation tolerance, it seems that these features are non-related to each other. C. acuminata seeds, for instance, were tolerant to dehydration and salinity, while $P$. elegans was sensitive to desiccation but tolerant to salinity. Similarly, Sané et al. (2005), when working with palm seedlings, analyzed the behavior of some Phoenix dactylifera L. varieties concerning to drought and salinity tolerance, and found that these two factors were independent. Furthermore, Ramoliya and Pandey (2003) studied the effect of soil and water salinity on $P$. dactylifera seedlings and observed that this species is salt tolerant at both seed germination and initial growth as they grew well up to $12.8 \mathrm{dS} \mathrm{m}^{-1}$ soil salinity. Since this species is a halophyte and; therefore, adapted to salt stress conditions because of the evolution of its osmotic regulation mechanism, $C$. acuminata and $P$. elegans may also be considered halophytes.

\section{Materials and Methods}

\section{Plant material}

Fruits of C. acuminata, P. canariensis, and P. elegans were harvested from different matrices in Limeira, São Paulo State, Brazil (22 $33^{\prime} 54^{\prime \prime} \mathrm{S}$ and $47^{\circ} 24^{\prime} 09^{\prime \prime} \mathrm{W}, 588 \mathrm{~m}$ altitude), while fruits of $D$. decaryi were harvested from different matrices in Jaboticabal, São Paulo State $\left(21^{\circ} 15^{\prime} 29^{\prime \prime} \mathrm{S}\right.$ and $48^{\circ} 16^{\prime} 47^{\prime \prime} \mathrm{W}, 600 \mathrm{~m}$ altitude). The experiment was conducted in Jaboticabal.

As the presence of the pericarp (epicarp and mesocarp) is a major limiting factor on germination of palm seeds (Andrade, 2001; Ehara et al., 2001; González-Benito et al., 2006; Chien and Chien, 2008; Jiménez et al., 2008), it was rapidly removed before initiating the germination tests, by manual friction against a steel mesh strainer under running water after the fruits have remained for 24 hours in water.

Biometric data (width and diameter) were recorded from a sample of 100 seeds (Gentil and Ferreira, 2005; Mendonça et al., 2008) of each species with the help of a digital caliper graded in millimeters (Mitutoyo model 500-321 CD-G). Mass of 1,000 seeds were also determined (Brasil, 2009).

\section{Treatments}

After cleaning, the initial moisture content of the 'seeds' (botanically a pyrene) was gravimetrically determined from two samples of 10 and 20 seeds, according to the seed size of each species, following oven drying at $103{ }^{\circ} \mathrm{C}$ for 17 hours (International Seed Testing Association, 2009). Desiccation tests were performed for four species: $C$. acuminata, eight seed moisture contents $(43.0 ; 38.5 ; 33.4 ; 28.0 ; 23.0 ; 18.0$; 13.0; and $8.0 \%)$; D. decaryi, 10 seed moisture contents (56.3; $50.9 ; 45.0 ; 40.0 ; 35.0 ; 30.0 ; 25.0 ; 20.0 ; 15.0$; and $10.0 \%) ; P$. canariensis, nine seed moisture contents $(45.0 ; 41.0 ; 35.2$; $30.0 ; 25.0 ; 20.0 ; 15.0 ; 10.0$; and 5.0\%); and P. elegans, eight seed moisture contents $(42.9 ; 37.4 ; 32.0 ; 27.0 ; 22.0 ; 17.0$; 12.0 ; and $7.0 \%$ ).

Seeds of each species were placed in desiccators with silica gel and their moisture contents were periodically determined until reaching a decreasing value up to $5 \%$ from the initial content, which was determined after harvest. The silica gel was replaced when its color changed from blue to pink, which is an indication of moisture in the silica.

For the salinity study, five $\mathrm{NaCl}$ solutions $(0,25,50,75$, and $100 \mathrm{mM}$ concentrations), with $0.65,2.15,4.31,6.32$, and $8.0 \mathrm{dS} \mathrm{m}^{-1}$ electrical conductivity, respectively, were used to moisten the vermiculite substrate for germination of $C$. acuminata and $P$. elegans seeds. Seed moisture contents of $C$. acuminata and $P$. elegans, which were determined as mentioned before, were $38.5 \pm 2.7 \%$ and $37.4 \pm 3.1 \%$, respectively, on a fresh weight basis.

\section{Experiment conduction and traits measured}

Seeds were sown in transparent polystyrene boxes $(11 \mathrm{x} 11 \mathrm{x}$ $3.5 \mathrm{~cm})$, filled with fine vermiculite, and placed under the alternating temperature of $20-30{ }^{\circ} \mathrm{C}$ with a photoperiod of 16 hour light and 8-hour darkness.

Seeds of all species were considered germinated when seedlings first appeared. Germination was then recorded every two days, until such process was steady, for determination of germination percentage, which was calculated by the formula proposed by Brasil (2009). Data of germination rate was calculated using the formula proposed by Maguire (1962).

\section{Statistical analysis}

The experimental design, for both experiments, was entirely randomized with four replications of 25 seeds each, for all species. Prior to the variance analysis, data of germination rate were transformed to $\arcsin (\mathrm{x} / 100)^{1 / 2}$. Data were then submitted to the variance analysis using SAS software (Schabenberger and Pierce, 2001; Delwiche and Slaughter, 2003). Polynomial regression analysis was also performed according to the method of orthogonal polynomials (PIMENTEL-GOMES, 2009) to verify the effect of the evaluated characteristics, such as seed moisture content and salinity, on seed germination.

\section{Conclusion}

The palm species Carpentaria acuminata and Phoenix canariensis are considered tolerant to desiccation, as seeds endured drying at 5\% and $8 \%$ seed moisture content, respectively. On the other hand, seeds of Dypsis decaryi and Phoenix elegans were sensitive to dehydration even at high seed moisture contents, $20 \%$ and $27 \%$, respectively. The increase on salt concentration did not affect germination percentage and germination rate of $C$. acuminata and $P$. elegans seeds, so both species were considered salt tolerant.

\section{Acknowledgments}

To the National Counsel of Technological and Scientific Development $(\mathrm{CNPq})$ for financial support to this research (Process 484299/2013-1) and a research productivity grant to the third author (Process 308086/2012-0). H.W. Pritchard acknowledges financial support from the Garfield Weston Foundation Global Tree Seed Project. The Royal Botanic Gardens, Kew receives grant-in-aid from Defra. 


\section{References}

Andrade ACS (2001) The effect of moisture content and temperature on the longevity of heart of palm seeds (Euterpe edulis). Seed Sci Technol. 29:171-182.

Berjak P, Pammenter NW (2008) From Avicennia to Zizania: seed recalcitrance in perspective. Ann Bot-London. 101(2):213-228

Bovi MLA, Martins CC, Spiering SH (2004) Desidratação de sementes de quatro lotes de pupunheira: efeitos sobre a germinação e o vigor. Hortic Bras. 22(1):109-112.

Brasil, Ministério da Agricultura, Pecuária e Abastecimento (2009) Regras para análise de sementes. Secretaria de Defesa Agropecuária, Brasília.

Carvalho JEU, Müller CH (1998) Níveis de tolerância e letal de umidade em sementes de pupunheira, Bactris gasipaes. Rev Bras Frutic. 20(3):283-289.

Carvalho JEU, Nascimento WMO, Müller CH (1998) Características físicas e de germinação de sementes de espécies frutíferas nativas da Amazônia. Embrapa-CPATU, Belém.

Chien CT, Chien SY (2008) Effects of seed moisture content and temperature on the storability of Phoenix hanceana (Arecaceae). Seed Sci Technol. 36(3):781-787.

Daws MI, Garwood NC, Pritchard HW (2005) Traits of recalcitrant seeds in a semi-deciduous forest in Panamá: some ecological implications. Funct Ecol. 19(5):874-885.

Delwiche LD, Slaughter SJ (2003) The little SAS book: a primer. SAS Institute, Cary.

Dias DS, Lopes PSN, Ribeiro LM, Oliveira LAA, Mendes EV, Carvalho VS (2015) Tolerance of desiccation and cryopreservation of Butia capitata palm seeds. Seed Sci Technol. 43(1):90-100.

Dickie JB, Pritchard HW (2002) Systematic and evolutionary aspects of desiccation tolerance in seeds. In: Black $\mathrm{M}$, Pritchard HW (ed) Desiccation and survival in plants: drying without dying. CAB International, Wallingford

Ditommaso A (2004) Germination behavior of common ragweed (Ambrosia artemisiifolia) populations across a range of salinities. Weed Sci. 52(6):1002-1009.

Ehara H, Morita O, Komada C, Goto M (2001) Effect of physical treatment and presence of the pericarp and sarcotesta on seed germination in sago palm (Metroxylon sagu Rottb.). Seed Sci Technol. 29(1):83-90

El Rabey HA, Al-Malki AL, Abulnaja KO, Rohde W (2015) Proteome analysis for understanding abiotic stress (salinity and drought) tolerance in date palm (Phoenix dactylifera $\mathrm{L}$.). Int $\mathbf{J}$ Genom. 2015:1-11.

Fernandes AR, Carvalho JG, Curi N, Guimarães PTG, Pinto JEBP (2003) Crescimento de mudas de pupunheira (Bactris gasipaes H.B.K.) sob diferentes níveis de salinidade. Cienc Agrotec. 27(2):278-284.

Ferreira SAN, Santos LA (1992) Viabilidade de sementes de pupunha (Bactris gasipaes Kunth). Acta Amaz. 22(3):303307.

Gentil DFO, Ferreira SAN (2005) Morfologia da plântula em desenvolvimento de Astrocaryum aculeatum Meyer (Arecaceae). Acta Amaz. 35(3):337-342.

González-Benito ME, Huertas-Micó M, Pérez-García F (2006) Seed germination and storage of Chamaerops humilis (dwarf fan palm). Seed Sci Technol. 34(1):143-150.

Hill JP, Edwards W, Franks PJ (2010) How long does it take for different seeds to dry? Funct Plant Biol. 37(6):575-583.

International Seed Testing Association (2009) International rules for seed testing. International Seed Testing Association, Bassersdorf.

Jaleel CA, Gopi R, Manivannan P, Panneerselvam R (2007) Antioxidative potentials as a protective mechanism in
Catharanthus roseus (L.) G. Don. plants under salinity stress. Turk J Bot. 31(1):245-251.

Jiménez VM, Guevara E, Herrera J, Alizaga R, Bangerth F (2008) Changes in hormone concentrations during dormancy release of oil palm (Elais guineensis) seeds. Seed Sci Technol. 36(3):575-587.

Lima MGS, Lopes NF, Moraes DM, Abreu CM (2005) Qualidade fisiológica de sementes de arroz submetidas a estresse salino. Rev Bras Sementes. 27(1):54-61.

Lopes JC, Macedo CMP (2008) Germinação de sementes de couve chinesa sob influência do teor de água, substrato e estresse salino. Rev Bras Sementes. 30(3):79-85.

Maguire JD (1962) Speed of germination - aid in selection and evaluation for seedling emergence and vigor. Crop Sci. 2(1):176-177.

Maluf AM, Bilia DAC, Barbedo CJ (2003) Drying and storage of Eugenia involucrata DC. seeds. Sci Agr. 60(3):471-475.

Marinho FJL, Gheyi HR, Fernandes PD (2005) Germinação e formação de mudas de coqueiro irrigadas com águas salinas. Rev Bras Eng Agr Amb. 9(3):334-340.

Martín Alemán N, León Hernández AM, Rodríguez Pérez JA (1999) Effect of salinity on germination of Phoenix canariensis and Sabal palmetto (Arecaceae). Acta Hortic. 486:209-2013.

Martins CC, Bovi MLA, Nakagawa J (2003) Desiccation effects on germination and vigor of king palm seeds. Hortic Bras. 21(1):88-92.

Martins CC, Nakagawa J, Bovi MLA (1999a) Tolerância à dessecação de sementes de palmito-vermelho (Euterpe espiritosantensis Fernandes). Rev Bras Bot. 22(3):391-396.

Martins CC, Nakagawa J, Bovi MLA, Stanguerlim H (1999b) Teores de água crítico e letal para sementes de açaí (Euterpe oleracea Mart. - Palmae). Rev Bras Sementes. 21(1):125-132.

Mendonça MS, Oliveira AB, Araújo MGP, Araújo LM (2008) Morfo-anatomia do fruto e semente de Oenocarpus minor Mart. (Arecaceae). Rev Bras Sementes. 30(1):90-95.

Nascimento WMO, Oliveira MSP, Carvalho JEU, Müller CH (2002) Influência da posição de semeadura na germinação, vigor e crescimento de plântulas de bacabinha (Oenocarpus mapora Karten - Arecaceae). Rev Bras Sementes. 24(1):179182.

Pammenter NW, Berjak P (2000) Evolutionary and ecological aspects of recalcitrant seed biology. Seed Sci Res. 10(3):301306.

Pimentel-Gomes F (2009) Curso de estatística experimental. FEALQ, Piracicaba.

Pritchard HW, Daws MI, Fletcher BJ, Gamene CS, Msanga HP, Omondi W (2004) Ecological correlates of seed desiccation tolerance in tropical African dryland trees. Am J Bot. 91(6):863-870.

Ramoliya PJ, Pandey AN (2003) Soil salinity and water status affect growth of Phoenix dactylifera seedlings. New Zeal J Crop Hort. 31(4):345-353.

Roberts EH (1973) Predicting the storage life of seeds. Seed Sci Technol. 1(3):499-514.

Sané D, Kneyta MO, Diouf D, Badiane FA, Sagna M, Borgel A (2005) Growth and development of date palm (Phoenix dactylifera L.) seedlings under drought and salinity stresses. Afr J Biotechnol. 4(9):968-972.

Schabenberger O, Pierce FJ (2001) Contemporary statistical models for the plant and soil sciences. CRC Press, New York.

Tester M, Davenport R (2003) $\mathrm{Na}^{+}$tolerance and $\mathrm{Na}^{+}$transport in higher plants. Ann Bot-London. 91(3):503-527.

Tweddle JC, Dickie JB, Baskin CC, Baskin JM (2003) Ecological aspects of seed desiccation sensitivity. J Ecol 91(2):294-304

Viana SBA, Fernandes PD, Gheyi HR, Soares FA, Carneiro PT (2004) Índices morfofisiológicos e de produção de alface sob estresse salino. Rev Bras Eng Agr Amb. 8(1):23-30. 